\title{
DETERMINAN PERINGKAT SUKUK KORPORASI PADA PASAR MODAL DI INDONESIA TAHUN 2014-2020
}

\author{
Eka Prasetya Agustin \\ Universitas Negeri Surabaya \\ ekaagustin1@mhs.unesa.ac.ic
}

\begin{abstract}
This section contains the This study aims to determine and provide empirical findings whether profitability, liquidity, leverage, productivity, firm size, and age of sukuk have an influence on sukuk ratings. The sample used is companies that issue sukuk and are listed on the Indonesia Stock Exchange. The data analysis technique uses multiple linear regression analysis with the help of SPSS 23. The results of this study indicate that the firm size and age of the sukuk have an effect on the sukuk rating. Meanwhile, profitability, liquidity, leverage, and productivity have no effect on the sukuk rating.

Keywords: sukuk; profitability, liquidity, leverage, productivity, firm size, maturity.
\end{abstract}

\begin{abstract}
ABSTRAK
Penelitian ini bertujuan untuk mengetahui dan menyediakan temuan secara empiris apakah profitabilitas, likuiditas, leverage, produktivitas, firm size, dan umur sukuk memiliki pengaruh terhadap peringkat sukuk. Sampel yang digunakan adalah perusahaan yang menerbitkan sukuk dan terdaftar di Bursa Efek Indonesia. Teknik analisis data menggunakan analisis regresi linear berganda dengan bantuan SPSS 23. Hasil penelitian ini menunjukkan bahwa firm size dan umur sukuk berpengaruh terhadap peringkat sukuk. Sedangkan profitabilitas, likuiditas, leverage, dan produktivitas tidak berpengaruh terhadap peringkat sukuk.
\end{abstract}

Kata Kunci: sukuk, profitabilitas, likuiditas, leverage, produktivitas, firm size, umur sukuk. 


\section{PENDAHULUAN}

Tujuan Dalam pasar modal syariah, terdapat salah satu instrumen keuangan yang biasa disebut dengan sukuk. Berdasarkan fatwa Dewan Syariah Nasional (DSN) Majelis Ulama Indonesia (MUI) nomor 32/DSN-MUI/IX/2002, sukuk merupakan surat berharga jangka panjang berdasarkan prinsip syariah yang dikeluarkan oleh emiten kepada pemegang sukuk yang mewajibkan emiten untuk membayarkan kepada pemegang sukuk berupa bagi hasil, serta membayar kembali pada saat jatuh tempo. Dijelaskan dalam Laporan Perkembangan Keuangan Syariah Indonesia (LPKSI) yang diterbitkan oleh Otoritas Jasa Keuangan (OJK) "sukuk adalah efek syariah berupa sertifikat atau bukti kepemilikan yang bernilai sama dan mewakili bagian yang tidak terpisahkan atau tidak terbagi (syuyu'/undivided share), atas aset yang mendasarinya." Berdasarkan definisi tersebut, dapat disimpulkan bahwa sukuk bukan merupakan surat utang, melainkan bukti kepemilikan bersama atas suatu aset/proyek. Dengan demikian, sukuk yang diterbitkan harus mempunyai aset yang dijadikan dasar penerbitan (underlying asset). Keberadaan underlying asset ini memberikan kejelasan sumber imbal hasil bagi pemegang sukuk. Pendapatan bagi pemegang sukuk dapat berupa imbalan, bagi hasil, atau marjin, sesuai dengan jenis akad yang digunakan dalam penerbitan sukuk (Kurniasari,
2014). Sukuk korporasi merupakan salah satu sumber pendanaan berbasis syariah yang sedang mengalami perkembangan di pasar modal syariah (Gambar 1.1). Selama 5 tahun terakhir, sukuk korporasi terlihat mengalami pertumbuhan yang positif pada tahun 2015 hingga 2020. Sampai dengan akhir tahun 2020 total sukuk yang telah diterbitkan berjumlah 274 seri dengan nominal sebesar $\mathrm{Rp} 55,15$ triliun. Nilai outstanding sukuk korporasi meningkat dari tahun 2019 menjadi Rp 30,35 triliun di tahun 2020. Serta jumlah sukuk outstanding sebanyak 162 seri yang naik dari tahun sebelumnya. Dalam menginvestasikan dananya ke instrumen pasar modal, investor akan mempertimbangkan harga dan kualitas dari instrumen tersebut. Sama halnya seperti obligasi, dalam transaksi sukuk, harga dan yield merupakan dua variabel penting yang harus dipertimbangkan oleh investor. Selain harga dan yield, peringkat juga dapat digunakan sebagai salah satu indikator untuk mengetahui kredibilitas perusahaan serta menilai ukuran risiko transaksi secara relatif. Semakin tinggi peringkat sukuk akan menyebabkan imbal hasil (yield) yang semakin rendah sehingga risiko gagal bayarnya menjadi rendah. Sedangkan peringkat yang semakin rendah akan menyebabkan imbal hasil (yield) yang semakin tinggi sehingga risiko gagal bayar pun juga semakin tinggi (Saputra \& 
Prasetiono, 2014).

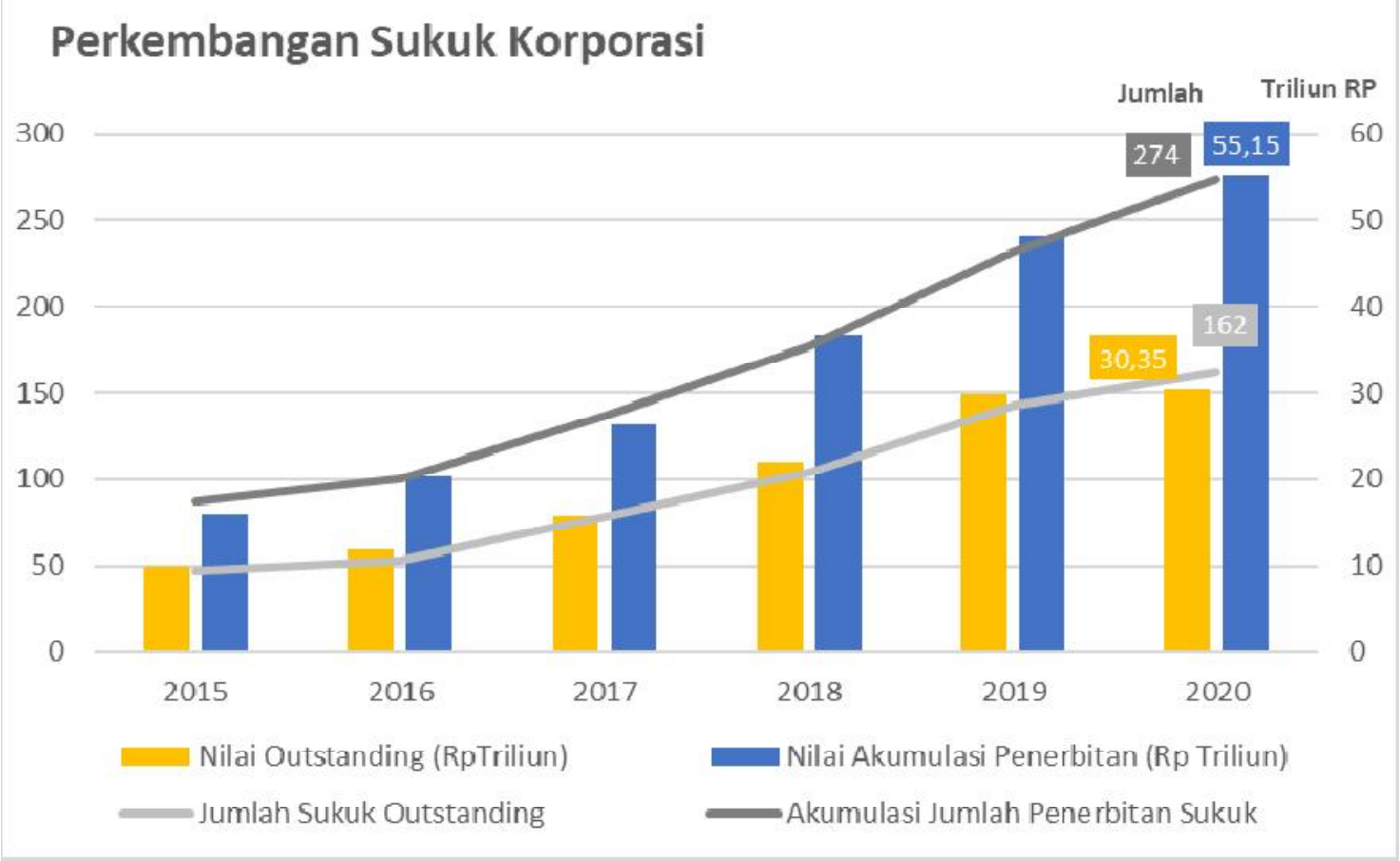

Gambar 1.1 Perkembangan Sukuk Korporasi Tahun 2015 - 2019

(Sumber: Otoritas Jasa Keuangan, 2019)

Peringkat obligasi maupun sukuk diberikan oleh lembaga pemeringkat utang atau credit rating agency. Salah satu Lembaga pemeringkat di Indonesia yang diakui oleh Otoritas Jasa Keuangan adalah PT. Pemeringkat Efek Indonesia (PEFINDO). Lembaga pemeringkat ini nantinya akan mengukur kelayakan kredit serta kemampuan emiten untuk melakukan pembayaran atas sukuk yang diterbitkan. Peringkat yang diberikan oleh lembaga pemeringkat ini akan menunjukkan apakah sukuk tersebut termasuk kedalam investment grade atau non investment grade. Metode penilaian tersebut dapat mencerminkan baik buruknya kondisi perusahaan sehingga dapat membantu investor dalam melakukan pertimbangan sebelum menginvestasikan dananya (Sudaryanti, Mahfudz, \& Wulandari, 2011). Dalam beberapa tahun terakhir, kerap terjadi kasus gagal bayar oleh perusahaan atas surat utangnya. Sebagai contoh adalah pada 27 Maret 2018, PEFINDO menurunkan peringkat dari PT. Express Transindo Utama dari BBmenjadi D karena perusahaan gagal melakukan pembayaran atas obligasi yang diterbitkan. Hal yang sama juga terjadi pada PT. Tiga Pilar Sejahtera Food Tbk yang juga mengalami gagal bayar atas obligasi dan sukuk ijarah yang diterbitkannya. PEFINDO menurunkan peringkat obligasi dan sukuk ijarah dari PT. Tiga Pilar Sejahtera Food Tbk menjadi D pada bulan Juli 2018 
(www.pefindo.com). Hal tersebut menunjukkan bahwa peringkat merupakan hal yang penting diketahui oleh investor karena dapat menunjukkan kondisi perusahaan. Semakin tinggi peringkat suatu obligasi atau sukuk, maka semakin rendah kemungkinan perusahan untuk mengalami gagal bayar. Penelitian terkait faktor-faktor yang dapat mempengaruhi peringkat sukuk pernah dilakukan oleh beberapa peneliti, akan tetapi terdapat inkonsistensi hasil penelitian. Seperti pada penelitian (Melis, 2014) yang menunjukkan bahwa profitabilitas dan leverage tidak berpengaruh pada peringkat sukuk. Sementara penelitian yang dilakukan oleh (Hadinata, 2020) menunjukkan hasil bahwa profitabilitas berpengaruh positif terhadap peringkat sukuk. Selain itu pada penelitian yang dilakukan oleh (Melinda \& Wardani, 2019) memberikan hasil bahwa leverage berpengaruh negatif terhadap peringkat sukuk. Penelitian yang dilakukan oleh (Elhaj, Muhammed, \& Ramli, 2015) menunjukkan hasil bahwa profitabilitas berpengaruh positif sementara leverage berpengaruh negatif terhadap peringkat sukuk. Penelitian lainnya yang dilakukan oleh (Arisanti, Fadah, \& Puspitasari, 2014) menunjukkan bahwa ukuran perusahaan tidak berpengaruh terhadap peringkat sukuk. Akan tetapi pada penelitian yang dilakukan oleh (Hadinata, 2020) menunjukkan bahwa ukuran perusahaan berpengaruh positif terhadap peringkat sukuk. Penelitian yang dilakukan oleh (Pramesti, 2017) juga menunjukkan bahwa ukuran perusahaan berpengaruh positif terhadap peringkat sukuk. Berdasarkan ketidakkonsistenan hasil penelitian di atas dan juga beberapa kejadian gagal bayar perusahan penerbit obligasi seperti PT. Express Transindo Utama dan PT. Tiga Pilar Sejahtera Food, serta melihat pentingnya peringkat sukuk bagi investor, memberikan motivasi kepada penulis untuk melakukan penelitian mengenai faktor-faktor apa saja yang sebenarnya mempengaruhi peringkat sukuk itu sendiri. Adapun variabel atau faktor yang digunakan penulis dalam penelitian ini antara lain profitabilitas, likuiditas, leverage, produktivitas, ukuran perusahaan, serta maturitas sukuk. Rentang waktu penelitian adalah tahun 2014-2020. Metode analisis penelitian yang digunakan dalam penelitian ini adalah analisis regresi. Penelitian ini diharapkan dapat membantu menambah pengetahuan untuk para pembaca mengenai salah satu instrumen dalam pasar modal syariah yaitu sukuk. Penelitian ini juga diharapkan dapat dijadikan referensi untuk penelitian selanjutnya dan juga untuk masyarakat yang ingin menginvestasikan dananya dalam memprediksi peringkat sukuk. 
TELAAH LITERATUR

\section{Teori Sinyal}

Teori sinyal merupakan bagian dari teori struktur modal yang dikembangkan oleh Modigliani dan Merton Melly pada tahun 1958. Teori ini menjelaskan mengenai pentignya informasi yang dikeluarkan oleh perusahaan terhadap keputusan berinvestasi dari pihak luar. Menurut (Jogiyanto, 2014), informasi yang dipublikasikan akan memberikan sinyal bagi investor. Pada saat informasi diumumkan, investor terlebih dahulu menganalisis informasi tersebut sebagai sinyal baik (good news) atau sinyal buruk (bad news). Jika pengumuman informasi tersebut dianggap sebagai sinyal baik, maka investor akan tertarik untuk melakukan investasi. Dalam transaksi obligasi maupun sukuk, rating atau peringkat merupakan suatu informasi atau sinyal yang menggambarkan probabilitas kegagalan utang dan risiko perusahaan. Informasi tersebut sangat membantu para investor yang ingin berinvestasi dalam bentuk obligasi, karena dari informasi tersebut investor akan mengetahui return yang akan diperoleh beserta risiko yang akan ditanggung.

\section{Peringkat Sukuk}

Peringkat sukuk harus diperhatikan oleh investor, apabila investor akan membeli sukuk karena peringkat sukuk dapat menunjukkan risiko sukuk. Risiko sukuk berhubungan dengan kemampuan perusahaan yang mengeluarkan sukuk untuk membayar pokok pinjaman dan bunga pada saat jatuh tempo. Membeli sukuk yang memilki peringkat $\mathrm{BBB}$ ke atas relatif lebih aman dibandingkan dengan obligasi berperingkat B ke bawah. Alasannya, obligasi yang memiliki peringkat B ke bawah memiliki yield yang tinggi, peringkat rendah, dan risiko default besar (Purwaningsih, 2008).

\section{Pengembangan Hipotesis}

\section{Pengaruh Profitabilitas Terhadap Peringkat Sukuk}

Profitabilitas merupakan salah satu dari rasio keuangan yang mengukur kemampuan fundamental perusahaan untuk menghasilkan keuntungan dari penjualan dan pendapatan investasi. Profitabilitas menggambarkan tingkat efisiensi dan efektivitas operasi perusahaan dalam rangka memperoleh laba. Dalam penelitian ini, rasio profitabilitas diproksikan dengan Return On Asset (ROA). Dalam penelitiannya, (Sudaryanti, Mahfudz, \& Wulandari, 2011) dan (Melis, 2014) menunjukkan bahwa profitabilitas tidak memiliki pengaruh terhadap peringkat sukuk. Akan tetapi, pada penelian (Elhaj, Muhammed, \& Ramli, 2015) menunjukkan bahwa terdapat pengaruh positif dari profitabilitas terhadap peringkat sukuk. Hal ini sejalan dengan hasil penelitian 
(Pebruary, 2016), Haraqi \& Ningsih (2017), serta (Pramesti, 2017) yang menunjukkan bahwa profitabilitas berpengaruh positif terhadap peringkat sukuk. Adanya pengaruh ini disebabkan karena pada umumnya semakin besar profitabilitas, maka semakin besar kemungkinan perusahaan untuk going concern dan memenuhi kewajibannya.

H1: Profitabilitas berpengaruh terhadap peringkat sukuk.

\section{Pengaruh Likuiditas Terhadap Peringkat Sukuk}

Rasio likuiditas merupakan rasio yang menggambarkan kemampuan perusahaan untuk memenuhi kewajiban jangka pendeknya dengan menggunakan aset lancar yang tersedia. Semakin tinggi rasio likuiditas suatu perusahaan menunjukkan bahwa perusahaan memiliki kemampuan untuk membayar seluruh kewajiban lancarnya. Rasio likuiditas dalam penelitian ini diproksikan dengan Current Ratio (CR). Dalam penelitian yang dilakukan oleh (Pramesti, 2017) menunjukkan hasil bahwa likuiditas berpengaruh negatif terhadap peringkat sukuk. Akan tetapi, penelitian yang dilakukan oleh (Melis, 2014) dan (Pebruary, 2016) menunjukkan hasil bahwa likuiditas memiliki pengaruh positif terhadap peringkat sukuk. Hal ini dikarenakan likuiditas yang tinggi dapat mengantisipasi apabila terjadi perubahan kondisi ekonomi ataupun keuangan, maka aset lancar tersebut dapat digunakan untuk memenuhi kewajiban perusahaan yang terkait dengan sukuk pada saat jatuh tempo. Hal ini dapat membuat para pemegang sukuk (investor) merasa aman untuk berinvestasi pada perusahaan tersebut karena likuiditas yang tinggi akan memperkecil risiko kegagalan sukuk, sehingga dapat mempengaruhi peringkat sukuk perusahaan tersebut.

H2: Likuiditas berpengaruh terhadap peringkat sukuk.

\section{Pengaruh Leverage Terhadap Peringkat} Sukuk

Leverage merupakan rasio untuk menilai kemampuan perusahaan dalam melunasi semua kewajibannya baik jangka pendek maupun jangka panjang dengan jaminan aset atau kekayaan yang dimiliki perusahaan hingga perusahaan tutup atau dilikuidasi. Dalam penelitian ini, leverage diproksikan dengan Debt to Equity Ratio (DER) yang membandingkan antara total kewajiban (liabilities) dengan ekuitas (equity). DER dapat menunjukkan seberapa jauh perusahaan dibiayai oleh utang dengan kemampuan perusahaan yang digambarkan oleh modal (equity). Penelitian (Melis, 2014) dan (Sudaryanti, Mahfudz, \& Wulandari, 2011) menunjukkan hasil bahwa leverage tidak memiliki pengaruh terhadap peringkat sukuk. Sedangkan penelitian yang 
dilakukan oleh (Elhaj, Muhammed, \& Ramli, 2015) dan (Pebruary, 2016) menunjukkan hasil bahwa leverage berpengaruh negatif terhadap peringkat sukuk. Hal ini dikarenakan semakin rendah rasio leverage suatu perusahaan menunjukkan porsi utang terhadap modal yang semakin kecil, sehingga mencerminkan kondisi perusahaan yang baik.

$\mathrm{H}_{3}$ : Leverage berpengaruh terhadap peringkat suku.

\section{Pengaruh Produktivitas Terhadap Peringkat Sukuk}

Produktivitas mencerminkan seberapa efektif penggunaan sumber daya perusahaan untuk menghasilkan atau menyelesaikan suatu kumpulan hasil (Mali, 1978). Produktivitas perusahaan diproksikan dengan total asset turn over, merupakan salah satu dari rasio aktivitas perusahaan (Lumapow \& Tumiwa, 2017). Dengan adanya produktivitas yang tinggi perusahaan mampu memperoleh uang yang lebih besar untuk digunakan dalam memenuhi seluruh kewajibannya. Rasio produktivitas dapat mempengaruhi peringkat sukuk. Produktivitas perusahaan yang semakin besar dapat meningkatkan peringkat sukuknya. Produktivitas yang tinggi bisa dilihat dari nilai penjualan yang tinggi juga, jika penjualan perusahaan tinggi maka akan memberi sinyal kepada pihak luar bahwa kemungkinan besar perusahaan itu mampu memenuhi kewajibannya sebelum jatuh tempo.

$\mathrm{H}_{4}$ : Produktivitas memiliki pengaruh positif terhadap peringkat sukuk.

\section{Pengaruh Ukuran Perusahaan}

\section{Terhadap Peringkat Sukuk}

Ukuran perusahaan merupakan suatu skala untuk mengukur dan menggolongkan besar kecilnya perusahaaan. Ukuran perusahaan dalam penelitian ini diukur dengan menggunakan total aset. Perusahaan yang memiliki nilai total aset besar memungkinkan untuk memiliki kemampuan memenuhi kewajibannya dengan menggunakan aset yang dimiliki perusahaan. Penelitian yang dilakukan oleh (Arisanti, Fadah, \& Puspitasari, 2014) menunjukkan bahwa ukuran perusahaan tidak memiliki pengaruh terhadap peringkat sukuk. Sedangkan penelitian (Pramesti, 2017) dan (Sudaryanti, Mahfudz, \& Wulandari, 2011) menunjukkan hasil bahwa ukuran perusahaan berpengaruh positif terhadap peringkat sukuk. Pada umumnya, semakin besar ukuran perusahaan yang dapat diukur dengan total aset, maka semakin besar kemungkinan perusahaan untuk mendapatkan peringkat sukuk yang tinggi. Hal ini karena perusahaan dengan ukuran yang lebih besar memiliki total aset yang lebih besar, sehingga memungkinkan perusahaan untuk memenuhi kewajibannya dengan menggunakan aset yang dimiliki 
perusahaan.

$\mathrm{H}_{5}$ : Ukuran perusahaan berpengaruh terhadap peringkat sukuk.

\section{Pengaruh Maturitas Sukuk Terhadap Peringkat Sukuk}

Setiap sukuk mempunyai masa jatuh tempo atau dikenal dengan istilah maturity date yang merupakan tanggal dimana nilai pokok sukuk harus dilunasi oleh penerbit sukuk. Penelitian yang dilakukan oleh (Sudaryanti, Mahfudz, \& Wulandari, 2011) menunjukkan hasil bahwa maturitas sukuk tidak berpengaruh terhadap peringkat sukuk. Akan tetapi, penelitian (Arisanti,

\section{METODOLOGI PENELITIAN}

\section{Jenis Penelitian}

Jenis penelitian yang digunakan dalam penelitian ini adalah penelitian kuantitatif. Metode penelitian kuantitatif merupakan metode penelitian yang didasarkan pada filsafat positivisme serta analisis data bersifat kuantitatif atau statistik dengan tujuan untuk menguji hipotesis yang telah ditetapkan. Penelitian kuantitatif dikatakan berdasarkan filsafat positivisme dikarenakan telah memenuhi kaidahkaidah ilmiah yang konkrit atau empiris, objektif, terukur, rasional, serta sistematis (Sugiyono, 2017).
Fadah, \& Puspitasari, 2014) dan (Elhaj, Muhammed, \& Ramli, 2015) menunjukkan bahwa maturitas sukuk memiliki pengaruh negatif terhadap peringkat sukuk. Sukuk yang memiliki jatuh tempo lebih lama cenderung memiliki risiko yang lebih besar dibandingkan dengan sukuk yang memiliki jatuh tempo lebih pendek sehingga maturitas sukuk yang pendek lebih diminati investor karena memiliki risiko yang lebih kecil. Hal ini menunjukkan bahwa semakin pendek maturitas sukuk suatu perusahaan, maka semakin baik peringkatnya. $\mathrm{H}_{6}$ : Maturitas sukuk berpengaruh terhadap peringkat sukuk.

\section{Jenis dan Sumber Data}

Data yang digunakan dalam penelitian ini merupakan jenis data sekunder. Data sekunder adalah sumber yang secara tidak langsung memberikan data kepada peneliti, misalnya melalui dokumen (Sugiyono, 2017). Data sekunder yang digunakan dalam penelitian berupa laporan tahunan perusahaan yang terdaftar di Bursa Efek Indonesia selama periode 2013-2019 yang diperoleh dari website resmi BEI (www.idx.co.id) serta data perusahaan yang menerbitkan sukuk dan rating sukuk yang diperoleh dari website resmi PEFINDO (www.pefindo.com). 


\section{Sampel Penelitian}

Sampel penelitian yang digunakan dalam penelitian ini yakni perusahaan yang menerbitkan sukuk dan beroperasi serta terdaftar di BEI dalam periode waktu penelitian 2015 hingga 2019. Metode sampling yang digunakan pada penelitian ini adalah purposive sampling, karena pengambilan sampel didasarkan pada beberapa kriteria tertentu sebagai berikut.

Tabel 1

Pemilihan Sampel

\begin{tabular}{|c|l|c|}
\hline NO & \multicolumn{1}{|c|}{ KRITERIA SAMPEL } & JUMLAH \\
\hline 1 & $\begin{array}{l}\text { Perusahaan yang menerbitkan sukuk dan terdaftar di } \\
\text { BEI selama 2014-2020 }\end{array}$ & 37 \\
\hline 2 & $\begin{array}{l}\text { Perusahaan yang memiliki sukuk beredar selama } \\
\text { periode penelitian 2014-2020 }\end{array}$ & 9 \\
\hline 3 & $\begin{array}{l}\text { Perusahaan yang memiliki laporan keuangan } \\
\text { lengkap periode 2013-2019 }\end{array}$ & 9 \\
\hline 4 & \begin{tabular}{l} 
Emiten dalam bentuk bank \\
\hline
\end{tabular} & \begin{tabular}{c} 
Jumlah Sampel Tiap Periode \\
\hline
\end{tabular} \\
\hline & Periode Penelitian & 49 \\
\hline
\end{tabular}

Sumber: Data diolah penulis, 2021

Variabel Penelitian dan Definisi Operasional Variabel

Penelitian ini melibatkan enam variabel yang terdiri atas satu variabel dependen dan lima variabel independen. Menurut (Sugiyono, 2017) variabel independen merupakan variabel yang mempengaruhi atau menjadi sebab berubah atau timbulnya variabel dependen. Sedangkan variabel dependen merupakan variabel yang dipengaruhi atau menjadi akibat adanya variabel independen. Adapun variabel dependen serta variabel independen yang digunakan dalam penelitian ini beserta pengukurannya dijabarkan dalam tabel dibawah ini. Variabel dependen yang digunakan dalam penelitian ini adalah peringkat sukuk. Mengacu pada penelitian yang dilakukan oleh (Pebruary, 2016), pengukuran variabel peringkat sukuk pada penelitian ini dilakukan dengan memberikan nilai pada masing-masing peringkat sukuk. Nilai terendah diberikan untuk peringkat sukuk terendah dan nilai tertinggi untuk peringkat sukuk tertinggi. Peringkat sukuk yang memiliki tanda plus memiliki nilai sama dengan satu peringkat obligasi di atasnya, karena tanda plus menunjukkan peringkat obligasi tersebut memiliki keamanan obligasi mendekati 
peringkat di atasnya. Variabel independen pertama yaitu profitabilitas diproksikan dengan rasio Return On Asset (ROA). Variabel independen kedua adalah variabel likuiditas diproksikan dengan Current Ratio (CR). Variabel independen ketiga adalah leverage. Dalam penelitian ini, leverage diproksikan dengan Debt to equity ratio (DER). Kemudian variabel keempat adalah produktivitas yang diproksikan dengan Total Asset Turnover. Selanjutnya variabel ukuran perusahaan diproksikan dengan menggunakan log natural total aset dengan tujuan agar mengurangi fluktuasi data yang berlebih. Variabel terakhir adalah maturitas sukuk. Dalam penelitian yang dilakukan oleh (Sudaryanti, Mahfudz, \& Wulandari, 2011), maturitas sukuk dibagi menjadi dua kategori yaitu sukuk dengan jatuh tempo lebih dari 5 tahun dan sukuk dengan jatuh tempo kurang dari 5 tahun. Sukuk dengan jatuh tempo lebih dari 5 tahun diberikan nilai 0 , sedangkan sukuk dengan jatuh tempo kurang dari 5 tahun diberi nilai 1 .

Tabel 2

Variabel Penelitian dan Pengukuran

\begin{tabular}{|c|c|c|c|c|c|}
\hline No. & Variabel & \multicolumn{4}{|c|}{ Pengukuran } \\
\hline \multicolumn{6}{|c|}{ Dependen } \\
\hline 1 & Peringkat Sukuk & $\begin{array}{l}\text { Peringkat } \\
\text { AAA } \\
\text { A } \\
\text { A } \\
\text { BBB }\end{array}$ & $\begin{array}{l}\frac{\text { Nilai }}{7} \\
7 \\
6 \\
5 \\
4\end{array}$ & $\begin{array}{l}\text { Peringkat } \\
\mathrm{BB}+ \\
\mathrm{BB} \\
\mathrm{CCC} \\
\mathrm{D}\end{array}$ & $\begin{array}{l}\text { Nilai } \\
4 \\
3 \\
2 \\
1\end{array}$ \\
\hline \multicolumn{6}{|c|}{ Independen : } \\
\hline 2 & Profitabilitas & \multicolumn{4}{|c|}{ Return on asset $=$ Laba Bersih/Total Aset $\times 100 \%$} \\
\hline 3 & Likuiditas & \multicolumn{4}{|c|}{ Current ratio $=$ Aset Lancar/Utang Lancar } \\
\hline 4 & Leverage & \multicolumn{4}{|c|}{ Debt to equity $=$ Total Utang/Ekuitas } \\
\hline 5 & Produktivitas & \multicolumn{4}{|c|}{ Total Asset Turnover $=$ Penjualan/Total Aset } \\
\hline 6 & Ukuran Perusahaan & \multicolumn{4}{|c|}{ Ln (Total Aset) } \\
\hline 7 & Maturitas Sukuk & \multicolumn{4}{|c|}{ Durasi penerbitan sampai dengan jatuh tempo } \\
\hline
\end{tabular}

Sumber : Data Diolah Penulis, 2021 


\section{HASIL DAN PEMBAHASAN}

STATISTIK DESKRIPTIF

Statistik deskriptif menggambarkan secara umum. Secara umum informasi informasi data penelitian secara umum yang tersedia mencakup mean, median, terkait objek yang diteliti, tanpa adanya maksimal, minimum, dan deviasi standar. analisis dan kesimpulan yang berlaku

Tabel 3

Statistik Deskriptif

\begin{tabular}{llllllll}
\hline & $\begin{array}{l}\text { Peringkat } \\
\text { Sukuk }\end{array}$ & Profitabilitas & Likuiditas & Leverage & Produktivitas & Firm & Umur \\
& & & & & & Size & Sukuk \\
\hline Mean & 5.7959 & -0.0493 & 1.0653 & 1.1294 & 0.3799 & 17.5123 & 0.3878 \\
\hline Minimum & 1.0000 & -2.6400 & 0.1500 & -44.9700 & 0.0200 & - & 0.0000 \\
& & & & & & 44.9700 & \\
\hline Maximum & 7.0000 & 0.6100 & 2.6600 & 25.0200 & 0.9800 & 37.1000 & 1.0000 \\
\hline Std. Dev & 1.7675 & 0.3976 & 0.7357 & 8.3115 & 0.2266 & 18.4541 & 0.4923 \\
\hline Observations & 49 & 49 & 49 & 49 & 49 & 49 & 49 \\
\hline
\end{tabular}

Sumber: Data Diolah, 2021

\section{Hasil Analisis Statistik}

Sebelum pelaksanaan uji hipotesis

berlangsung, diperlukan serangkaian uji asumsi klasik yaitu uji normalitas dengan memakai tes Kolmogorof Smirnov, uji Uji Koefisien Determinasi $\left(\mathbf{R}^{2}\right)$

multikolinearitas, uji heteroskedastisitas, dan uji autokorelasi. Menurut hasil pengujian tersebut, model telah memenuhi prasyarat asumsi klasik.

Tabel 4

Hasil Koefisien Determinasi

\begin{tabular}{lllllll}
\hline Model & R & R Square & $\begin{array}{l}\text { Adj. } \\
\text { Square }\end{array}$ & $\begin{array}{l}\text { R } \\
\text { Std. Error of the } \\
\text { estimate }\end{array}$ & $\begin{array}{l}\text { Durbin- } \\
\text { Watson }\end{array}$ \\
\hline $\mathbf{1}$ & $.692^{\mathrm{a}}$ & .479 & .404 & 1.36407 & .778
\end{tabular}

Sumber: Output spss (data diolah)

Tabel di atas menggambarkan bahwasanya $R$ Square bernilai 0,479 yang berarti bahwa besarnya pengaruh variabel Profitabilitas, Likuiditas, Produktivitas, Leverage, Firm Size, dan Umur Sukuk terhadap Peringkat Sukuk sebesar 0,479 atau $47,9 \%$. Sisanya sebanyak $52,1 \%$ dipengaruhi oleh variabel lainnya diluar bahasan studi ini. 
Uji Signifikansi Simultan (Uji F)

Tabel 5

Hasil Uji F

\begin{tabular}{|c|c|c|c|c|c|}
\hline Model & $\begin{array}{l}\text { Sum } \\
\text { Squares }\end{array}$ & of Df & Mean Square & $\mathbf{F}$ & Sig. \\
\hline 1 & 71.810 & 6 & 11.968 & 6.432 & $.000^{\mathrm{b}}$ \\
\hline Regression & & & & & \\
\hline
\end{tabular}

$\begin{array}{lll}78.149 & 42 & 1.861\end{array}$

Residual

Total $149.959 \quad 48$

Sumber: Output spss (data diolah)

Data pada tabel 5 memperlihatkan nilai $\mathrm{F}$ mencapai 0,05 , jadi kesimpulannya hitung sebanyak 6,432 dengan level variabel variabel Profitabilitas, Likuiditas, signifikansi sebesar 0,000 dan $\mathrm{F}$ tabel Produktivitas, Leverage, Firm Size, dan sebanyak 2,32. Karena F hitung lebih Umur Sukuk berpengaruh secara simultan tinggi dari $\mathrm{F}$ tabel beserta nilai sig tidak terhadap Peringkat Sukuk. Uji Signifikansi Parsial (Uji T)

Tabel 6

Hasil Uji T

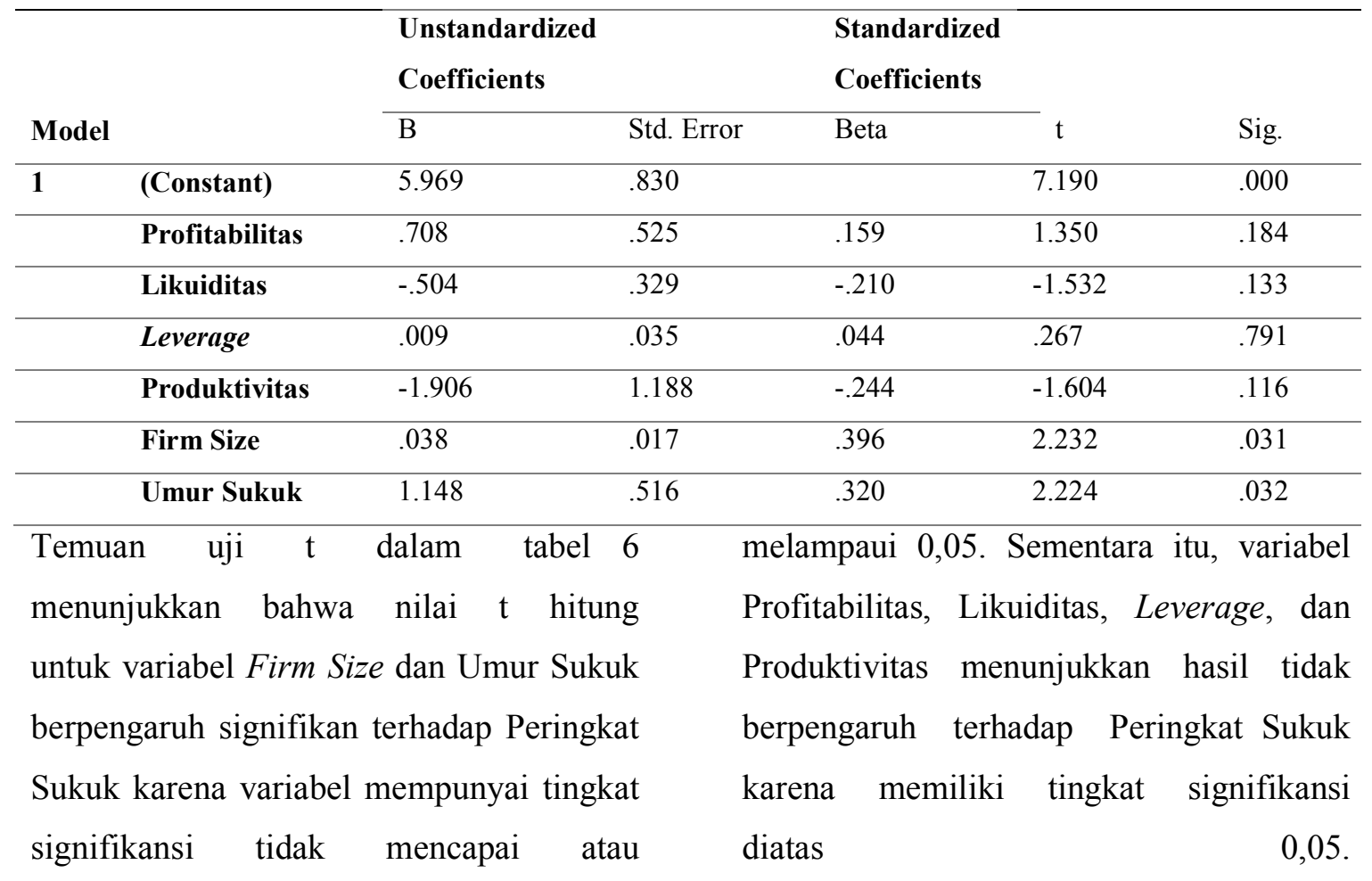




\section{PEMBAHASAN}

Pengaruh Profitabilitas Terhadap

Peringkat Sukuk

Profitabilitas merupakan salah satu dari rasio keuangan yang mengukur kemampuan fundamental perusahaan untuk menghasilkan keuntungan dari penjualan dan pendapatan investasi. Profitabilitas menggambarkan tingkat efisiensi dan efektivitas operasi perusahaan dalam rangka memperoleh laba. Dalam penelitian ini, rasio profitabilitas diproksikan dengan Return On Asset (ROA) dengan rumus Total Net Income dibagi dengan Total Asset. Return On Asset ini digunakan untuk melihat sejauh mana investasi yang telah ditanamkan mampu memberikan pengembalian keuntungan sesuai yang diharapkan. Berdasarkan hasil uji parsial studi menunjukkan bahwa tingkat signifikansi variabel profitabilitas adalah sebesar 0,184 atau lebih besar dari 0,05 sehingga menyebabkan $\mathrm{H}_{0}$ diterima dan $\mathrm{H}_{1}$ ditolak. Hasil ini menjelaskan bahwa variabel profitabilitas tidak berpengaruh signifikan terhadap peringkat sukuk. Penelitian yang memiliki hasil yang sama dilakukan (Winanti, Nurlaela, \& Titisari, 2017) dan (Melis, 2014). Kedua penelitian ini menunjukkan hasil bahwa variabel profitabilitas tidak berpengaruh terhadap peringkat sukuk. Hasil ini berbeda dengan penelitian yang dilakukan oleh (Pebruary, 2016) dan (Sudaryanti, Mahfudz, \& Wulandari, 2011) yang menunjukkan bahwa profitabilitas berpengaruh positif terhadap peringkat sukuk. Perbedaan ini kemungkinan terjadi karena adanya perbedaan kondisi laba atau rugi pada perusahaan selama jangka waktu penelitian.

\section{Pengaruh Likuiditas Terhadap Peringkat Sukuk}

Likuiditas merupakan rasio yang menggambarkan kemampuan perusahaan untuk memenuhi kewajiban jangka pendeknya dengan menggunakan aset lancar yang tersedia. Semakin tinggi rasio likuiditas suatu perusahaan menunjukkan bahwa perusahaan memiliki kemampuan untuk membayar seluruh kewajiban lancarnya. Rasio likuiditas dalam penelitian ini diproksikan dengan Current Ratio (CR) yang dapat memberikan gambaran kemampuan perusahaan untuk membayar kewajiban lancarnya. Berdasarkan hasil uji $\mathrm{T}$ menunjukkan bahwa variabel likuiditas memiliki tingkat signifikansi sebesar 0,133 atau lebih besar dari 0,05 sehingga menyebabkan $\mathrm{H}_{0}$ diterima dan $\mathrm{H}_{2}$ ditolak. Hasil ini menjelaskan bahwa variabel likuiditas tidak memiliki pengaruh terhadap peringkat sukuk. Hasil penelitian ini sejalan dengan penelitian yang dilakukan oleh (Winanti, Nurlaela, \& Titisari, 2017) yang menunjukkan bahwa profitabilitas tidak berpengaruh terhadap peringkat sukuk. Penelitian dengan hasil berbeda dilakukan oleh (Pramesti, 2017) yang 
menunjukkan bahwa likuiditas berpengaruh negatif terhadap peringkat sukuk. Perbedaan ini terjadi karena perbedaan tahun penelitian, dimana pasti terdapat ketidaksamaan kondisi perusahaan pada setiap tahunnya.

\section{Pengaruh Leverage Terhadap Peringkat}

\section{Sukuk}

Leverage merupakan rasio untuk menilai kemampuan perusahaan dalam melunasi semua kewajibannya baik jangka pendek maupun jangka panjang dengan jaminan aset atau kekayaan yang dimiliki perusahaan hingga perusahaan tutup atau dilikuidasi. Dalam penelitian ini, leverage diproksikan dengan Debt to Equity Ratio (DER) yang digunakan untuk menunjukkan apakah keuangan perusahaan dalah kondisi yang sehat atau tidak. Berdasarkan hasil uji parsial menunjukkan bahwa variabel leverage memiliki tingkat signifikansi sebesar 0,791 atau lebih besar dari 0,05 sehingga menyebabkan $\mathrm{H}_{0}$ diterima dan $\mathrm{H}_{3}$ ditolak. Hasil ini menjelaskan bahwa variabel leverage tidak memiliki pengaruh terhadap peringkat sukuk. Hasil ini mendukung hasil penelitian (Melis, 2014) dan (Sudaryanti, Mahfudz, \& Wulandari, 2011) yang juga menunjukkan hasil bahwa leverage tidak memiliki pengaruh terhadap peringkat sukuk. Hasil yang berbeda terdapat pada penelitian (Melinda \& Wardani, 2018) dan (Pebruary, 2016) yang menunjukkan hasil bahwa leverage berpengaruh negative terhadap peringkat sukuk. Perbedaan ini terjadi karena pada penelitian ini didapati bahwa beberapa perusahaan yang menerbitkan sukuk selama jangka waktu penelitian sedang dalam kondisi keuangan yang kurang bagus yang ditunjukkan oleh lebih besarnya jumlah utang perusahaan daripada modal atau ekuitasnya

\section{Pengaruh Produktivitas Terhadap Peringkat Sukuk}

Produktivitas mencerminkan seberapa efektif penggunaan sumber daya perusahaan untuk menghasilkan atau menyelesaikan suatu kumpulan hasil. Produktivitas perusahaan diproksikan dengan Total Asset Turn Over, yang merupakan salah satu dari rasio aktivitas perusahaan. Rasio ini digunakan untuk mengetahui maksimum penjualan dengan menggunakan aktiva tetap. Dengan adanya produktivitas yang tinggi perusahaan mampu memperoleh uang yang lebih besar untuk digunakan dalam memenuhi seluruh kewajibannya. Berdasarkan hasil uji $\mathrm{T}$ menunjukkan bahwa produktivitas memiliki tingkat signifikansi sebesar 0,116 atau lebih besar dari 0,05 sehingga menyebabkan $\mathrm{H}_{0}$ diterima dan $\mathrm{H}_{4}$ ditolak. Hasil ini menjelaskan bahwa variabel produktivitas tidak memiliki pengaruh terhadap peringkat sukuk. Hal ini dikarenakan selama jangka waktu penelitian, beberapa perusahaan memiliki rasio produktivitas yang kurang baik sehingga dapat dikatakan perusahaan- 
perusahaan tersebut belum mampu memenuhi seluruh kewajibannya dari penjualan yang mereka hasilkan.

\section{Pengaruh Firm Size (Ukuran}

Perusahaan) Terhadap Peringkat Sukuk

Pada umumnya, ukuran perusahaan digambarkan menggunakan total aset. Perusahaan yang berukuran besar biasanya memiliki nilai total aset yang besar, sehingga memungkinkan perusahaan untuk memiliki kemampuan memenuhi kewajibannya dengan menggunakan aset yang dimiliki perusahaan. Kemampuan tersebut yang dapat menyebabkan perusahaan mendapatkan peringkat sukuk yang tinggi, karena jauh dari risiko gagal bayar. Maka dapat disimpulkan bahwa semakin besar ukuran perusahaan, maka peringkat sukuknya akan semakin tinggi. Berdasarkan hasil uji parsial studi menunjukkan bahwa variabel firm size atau ukuran perusahaan memiliki nilai signifikansi sebesar 0,031 atau lebih kecil dari 0,05 sehingga menyebabkan $\mathrm{H}_{0}$ ditolak dan $\mathrm{H}_{5}$ diterima. Hasil ini menjelaskan bahwa firm size memiliki pengaruh signifikan terhadap peringkat sukuk. Nilai signifikansi yang positif menunjukkan bahwa terdapat pengaruh positif firm size terhadap peringkat sukuk. Hasil penelitian ini sejalan dengan penelitian yang dilakukan oleh (Hadinata, 2020), Rifqi (2019) (Pramesti, 2017) dan
(Sudaryanti, Mahfudz, \& Wulandari, 2011) yang menunjukkan hasil bahwa ukuran perusahaan berpengaruh positif terhadap peringkat sukuk.

\section{Pengaruh Umur Sukuk Terhadap Peringkat Sukuk}

Umur sukuk (maturity) merupakan salah satu dasar pertimbangan investor untuk melakukan investasi. Sukuk yang memiliki jatuh tempo lebih lama cenderung memiliki risiko yang lebih besar dibandingkan dengan sukuk yang memiliki jatuh tempo lebih pendek sehingga maturitas sukuk yang pendek lebih diminati investor karena memiliki risiko yang lebih kecil. Selain itu, umur sukuk yang lebih pendek memungkinkan perusahaan untuk mengembalikan pokok dan fee sesuai dengan perjanjian diawal. Berdasarkan hasil uji T studi menunjukkan bahwa variabel umur sukuk memiliki tingkat signifikasi sebesar 0,032 atau lebih kecil dari 0,05 sehingga menyebabkan $\mathrm{H}_{0}$ ditolak dan $\mathrm{H}_{6}$ diterima. Hasil ini menjelaskan bahwa variabel umur sukuk memiliki pengaruh signifikan terhadap peringkat sukuk. Penelitian dengan hasil yang sama dilakukan oleh (Hadinata, 2020), (Arisanti, Fadah, \& Puspitasari, 2014), dan (Elhaj, Muhammed, \& Ramli, 2015) yang menunjukkan bahwa umur sukuk berpengaruh terhadap peringkat sukuk. 


\section{SIMPULAN}

Berdasarkan hasil penelitian yang telah dijelaskan sebelumnya, dapat ditarik kesimpulan sebagai berikut. Variabel profitabilitas tidak berpengaruh terhadap peringkat sukuk. Variabel likuiditas tidak berpengaruh terhadap peringkat sukuk. Variabel leverage tidak berpengaruh terhadap peringkat sukuk. Variabel produktivitas tidak berpengaruh terhadap peringat sukuk. Variabel ukuran perusahaan berpengaruh terhadap peringkat sukuk. Variabel maturitas berpengaruh terhadap peringkat sukuk. Hasil ini menunjukkan bahwa ukuran perusahaan dan maturitas sukuk merupakan hal yang harus diperhatikan investor untuk menginvestasikan dananya. Semakin besar ukuran perusahaan yang diukur dengan total aset memungkinkan perusahaan untuk memiliki kemampuan

\section{DAFTAR PUSTAKA}

Adams, M., Barton, B., \& Hardwick, P. (2003). The Determinants of Credit Ratings in the United Kingdom Insurance Industry. Jurnal of Business Finance and Accounting, Vol. 30, No. $3 \& 4,439-572$.

Afiani, D. (2013). Pengaruh Likuiditas, Produktivitas, Profitabilitas, dan Leverage Terhadap Peringkat Sukuk (Studi Empiris pada Bank Umum Syariah dan Unit Usaha Syariah Periode 2008-2010). memenuhi kewajibannya dengan menggunakan aset yang dimiliki perusahaan, sehingga risiko gagal bayarnya tidak besar. Selain ukuran perusahaan, umur atau maturitas sukuk juga perlu diperhatikan oleh investor karena umur sukuk yang panjang memiliki risiko yang lebih besar untuk investor, sebab perusahaan akan menghadapi kondisi yang tidak pasti di masa depan. Penelitian ini memiliki keterbatasan yaitu kecilnya jumlah sampel. Hal ini dikarenakan pada tahun 2014 hingga 2020 perusahaan yang menerbitkan sukuk belum terlalu banyak. Saran untuk penelitian selanjutnya adalah agar menambah tahun penelitian sehingga sampel yang akan diteliti dapat berjumlah lebih besar dan mendapatkan hasil lebih maksimal.

Accounting Analysis Journal, Vol. 2, No. 1, 110-115.

Arisanti, I., Fadah, I., \& Puspitasari, N. (2014). Analisis Faktor Keuangan dan Non Keuangan yang Mempengaruhi Prediksi Peringkat Obligasi Syariah (Studi Empiris pada Perusahaan Penerbit Obligasi Syariah yang Terdaftar di Burs Efek Indonesia Periode 20102012). Jurnal Ekonomi Akuntansi dan Manajemen, 1-13. 
Arundina, T., Omar, M. A., \& Kartiwi, M. (2015). The Predictive Accuracy of Sukuk Ratings; Multinomial Logistic and Neural Network Inferences. Pacific-Basin Finance Journal, 34, 273-292. Pacific-Basin Finance Journal, Vol. 34, 273-202.

Borhan, N. A., \& Ahmad, N. (2018). Identifying The Determinants of Malaysian Corporate Sukuk Rating. International Journal of Islamic and Middle Eastern Finance and Management, Vo. 11, No. 3, 432448.

Elhaj, M. A., Muhammed, N., \& Ramli, N. M. (2015). The Influence of Corporate Governance, Financial Ratios, and Sukuk Structure on Sukuk Rating. Procedia Economics and Finance, 31(McMillen 2007), 62-74.

doi:https://doi.org/10.1016/s22125671(15)01132-6

Hadinata, S. (2020). Determinan Peringkat Sukuk: Ditinjau dari Aspek Akuntansi dan Non-Akuntansi. Wahana Riset Akuntansi, Vol. 8, No. 2, 95-107.

Haraqi, M. S., \& Ningsih, E. S. (2017). Pengaruh Return on Asset, Secure dan Maturity Terhadap Rating Sukuk. Jurnal Ilmiah Mahasiswa Ekonomi Akuntansi (JIMEKA), Vol. 2, No. 4, 116-124.

Jogiyanto. (2014). Teori Portofolio dan
Analisis Investasi (edisi ke 10) . Yogyakarta: BPFE.

Kurniasari, W. (2014). Perkembangan Dan Prospek Sukuk Tinjauan Teoritis. Muqtasid: Jurnal Ekonomi Dan Perbankan Syariah, Vol. 5, No. 1, 99.

doi:https://doi.org/10.18326/muqtas id.v5i1.99-122

Lumapow, L. S., \& Tumiwa, R. A. (2017). The Effect of Dividend Policy, Firm Size, and Productivity to The Firm Value. Research Journal of Finance and Accounting, Vol. 8, No. 22, 20-24.

Majelis Ulama Indonesia. (2002). Fatwa $D S N-M U I$

No.32/DSNMUI/IX/2002, tentang Obligasi Syariah. Jakarta: Majelis Ulama Indonesia.

Meirinaldi, \& Astuti, P. (2017). Analisa Faktor-Faktor yang Mempengaruhi Peringkat Sukuk (Studi Kasus Pada Perusahaan Penerbit Sukuk Non Keuangan). Jurnal Ekonomi, Vol. 19, No. 2, 198-209.

Meli, P. (1978). Improving Total Productivity. Canada: John Wiley and Sons Inc.

Melinda, D., \& Wardani, M. K. (2018). Faktor-Faktor yang Mempengaruhi Peringkat Sukuk Pada Perusahaan Penerbit Sukuk di Bursa Efek Indonesia. Kompartemen: Jurnal Ilmiah Akuntansi, Vol. 16, No. 2, 
69-90.

doi:https://doi.org/10.30595/kompa rtemen.v16i2.4742

Melis, K. (2014). Analisis Faktor-Faktor yang Mempengaruhi Rating Sukuk. Jurnal Ilmiah Mahasiswa FEB Universitas Brawijaya, Vol. 3, No. $2,1-21$.

Muhammad, R., \& Biyantoro, C. T. (2019). aktor-Faktor yang Mempengaruhi Peringkat Sukuk (Studi Empiris Perusahaan yang Diperingkat Fitch Rating). AlMasraf (Jurnal Lembaga Keuangan Dan Perbankan), Vol. 4, No. 2, 187-200.

Otoritas Jasa Keuangan . (2021, Juli 12).

Pasar Modal Syariah. . Diambil kembali dari ojk.go.id: https://www.ojk.go.id/id/kanal/syar iah/pages/pasar-modal-syariah.aspx

Pebruary, S. (2016). Pengaruh Profitabilitas, Rasio Likuiditas, Rasio Leverage Dan Pendapatan Bunga Terhadap Rating Sukuk Korporasi Periode 2010-2013. Jurnal Dinamika Ekonomi \& Bisnis, Vol. 13, No. 1, 94-112.

Pramesti, W. (2017). Analisis Pemeringkatan Sukuk: Perspektif Keuangan. Jurnal Bisnis dan Manajemen Islam, Vol. 5, No. 1,
93-110.

Purwaningsih, A. (2008). Pemilihan Rasio Keuangan Terbaik untuk memprediksi Peringkat Obligasi: Studi pada Perusahaan Manufaktur yang Terdaftar di BEJ. Jurnal: Kinerja, Volume 12, No.1, 85-99.

Saputra, \& Prasetiono. (2014). Analisis Faktor-Faktor yang Mempengaruhi Yield Obligasi Konvensional di Indonesia (Studi Kasus pada Perusahaan Listed di BEI). Jurnal Manajemen Dan Organisasi, 11, 67-77. Jurnal Manajemen Dan Organisasi, Vol. 11, 67-77.

Sudaryanti, Mahfudz, \& Wulandari. (2011). Analisis Determinan Peringkat Sukuk Dan Peringkat. Tazkia: Islamic Finance \& Business Review, Vol. 6, No. 2, 105-137.

Sugiyono. (2017). Metode Penelitian Kuantitatif, Kualitatif dan $R \& D$ (edisi 26). Bandung: Alfabeta.

Winanti, Nurlaela, \& Titisari. (2017). Pengaruh Rasio Likuiditas, Rasio Produktivitas, Rasio Profitabilitas, dan Rasio Solvabilitas Terhadap Peringkat Sukuk. . Jurnal Akuntansi Dan Pajak, Vol. 18, No. 01 , 130-139. 